\section{(D) Check for updates}

Cite this: Dalton Trans., 2021, 50 689

Received 15th November 2020, Accepted 2nd December 2020

DOI: 10.1039/d0dt03915b

rsc.li/dalton

\title{
A rigid anionic Janus bis(NHC) - new opportunities in NHC chemistry ${ }^{\dagger}$
}

\author{
Nabila Rauf Naz, ${ }^{a}$ Gregor Schnakenburg, ${ }^{a}$ Zsolt Kelemen, ${ }^{b}$ Dalma Gál, \\ László Nyulászi, (D) *b René T. Boeré (iD) *c and Rainer Streubel (D)*a
}

\begin{abstract}
A phosphanido-type bridged bis(imidazolium) salt, readily prepared in two steps via reductive deselenization of a tricyclic 1,4-diphosphinine diselone, affords access to a novel anionic P-functional tricyclic bis $(\mathrm{NHC})$ via deprotonation. The former also offers a P-functionalization/deprotonation sequence to access the first mixed P-substituted tricyclic bis(NHCs), as well as coordination of the phosphorus centers to rhodium(।) fragments.
\end{abstract}

\section{Introduction}

Owing to the wide range of structural and property modifications of N-heterocyclic carbenes (NHCs), they have become potent ligands in organometallic chemistry and catalysis. ${ }^{1,2}$ It has been reported that the incorporation of an anionic functionality confers higher stability to resulting NHC complexes compared to related neutral donor substituents. ${ }^{3}$ Backbonefunctionalized NHCs having anionic heteroatom substituents especially facilitate $\pi$-electron interactions with the heterocyclic ring, which can lead to electronic tuning of the donor properties of the carbene. ${ }^{4}$ Only a small number of NHCs of type $\mathbf{I}$ possessing an anionic low-coordinate moiety such as enolate, ${ }^{5}$ borate, ${ }^{6}$ amido $^{7}$ and phosphanido, ${ }^{8}$ have been re-ported (Fig. 1). Some of these enabled an additional and/or competing metal binding site, resulting in ligand polytopicity or ambidenticity in bimetallic coordination. ${ }^{9,10}$ The anionic bis-(NHC) II has been reported, obtained via reduction of a bis-(imidazol2-thione-4-yl)phosphane using a large excess of potassium metal; ${ }^{11}$ but II could neither be isolated nor structurally confirmed.

A new ambidentate Janus-type ligand combining a carbene and an anionic imidate centers within the same

\footnotetext{
${ }^{a}$ Institut für Anorganische Chemie der Rheinischen Friedrich-Wilhelms-Universität Bonn, Gerhard-Domagk-Strasse 1, 53121 Bonn, Germany.

E-mail: r.streubel@uni-bonn.de; http://anorganik.chemie.uni-bonn.de/akstreubel ${ }^{b}$ Department of Inorganic and Analytical Chemistry and MTA-BME Computation Driven Chemistry Research Group, Budapest University of Technology and Economics, Szt Gellert ter 4, 1111 Budapest, Hungary.

E-mail: nyulaszi@mail.bme.hu

${ }^{c}$ Department of chemistry and biochemistry, University of Lethbridge, 4401 University Drive West, Lethbridge, AB, T1K3M4, Canada. E-mail: boere@uleth.ca

$\dagger$ Electronic supplementary information (ESI) available. CCDC 2032731 and 2032732. For ESI and crystallographic data in CIF or other electronic format see DOI: $10.1039 /$ dodt03915b
}

heterocyclic framework was reported by Lavigne et al., appears to be suitable for the directed construction of a variety of homo-and/or heteropolymetallic complexes. ${ }^{3 c}$ In 2017 , a dianionic bis(maloNHC) ${ }^{3 d}$ was reported as a bridging ligand to construct zwitterionic complexes by Tapu et al. Furthermore, it served as building block for the preparation of novel organometallic frameworks, not handy with neutral Janus-type bis(NHC)s. Due to their unique electronic properties, these zwitterionic NHC-metal species exhibit potentially valuable advantages such as enhanced catalytic activity and solubility relative to the classical cationic metal complexes of the neutral NHCs.

Recently, we established a new series of tricyclic rigid Janus bis(NHCs) III, tuned by $\mathrm{PR}_{\mathrm{n}}$ moieties in different phosphorus oxidation states, and reported on their use in coinage metal(I) complex chemistry. ${ }^{12}$ Thereafter, continuing efforts have been made to establish anionic low-coordinate P-linked bis(NHCs) in order to achieve tuneable electronic communication and redox activity.

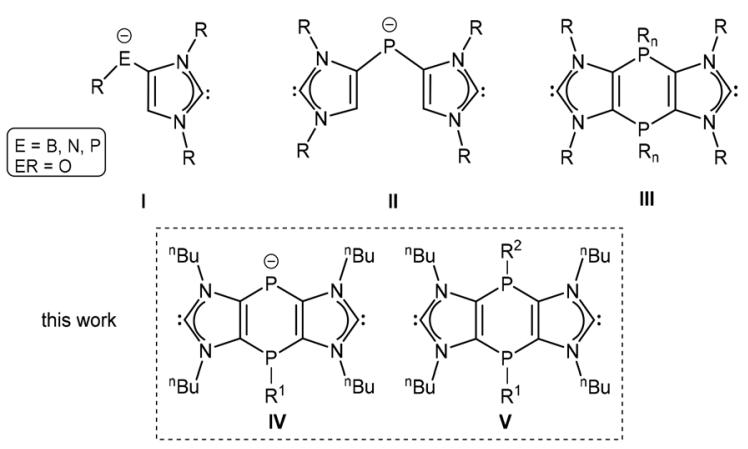

Fig. 1 Anionic mono and bis(NHCs) I, II and rigid Janus bis(NHCs) III-V $\left(R, R^{1}, R^{2}=\right.$ organic substituents). 
Herein, we report on the synthesis of a stable anionic Janus-type tricyclic bis(NHC) IV having a P-localized charge, and its use in main group and transition metal chemistry to access, e.g., bis(NHCs) V, having a mixed P-substitution pattern.

\section{Results and discussion}

\section{Synthesis of anionic bis(NHC) 4 via reductive deselenization}

Following our recent synthetic protocol, ${ }^{13}$ the new tricyclic 1,4 diphosphinine diselone $\mathbf{1}$ (Scheme 1) was synthesized via mild reduction of the $P-\mathrm{Cl}$ substituted 1,4-dihydro-1,4-diphosphi-nine ${ }^{12}$ precursor and, finally, isolated as a deep violet solid. According to TD-DFT calculations, the colour of this electron-delocalized compound could be attributed to a HOMO-LUMO transition (details in the ESI $\dagger$ ). Diselone 1 has been treated with 2 equivalents of trifluoromethyl methylsulfonate (MeOTf) in dichloromethane to afford the doubly Se-methylated salt 2 which was isolated as a yellow solid and fully characterized, including single crystal X-ray diffraction analysis (Fig. 2).

The centrosymmetric molecular structure of 2 has a C2-Se1 bond distance of 1.896(4) A that is slightly elongated compared to $1.8240(16) \AA$ for $\mathrm{C}=\mathrm{Se}$ in the precursor 1 (ESI $\dagger$ ), but remains significantly shorter than the 1.952(4) A Se-C8 bond to the methyl group.

Doubly Se-methylated salt 2 was subjected to reductive deselenization with $\mathrm{NaBH}_{4}$ in the presence of [2.2.2]-cryptand in methanol to afford (somewhat surprisingly) bis(imidazolium) salt 3 (Scheme 1) with an anionic phosphorus centre. Salt 3, obtained in pure form via extraction with dichloromethane followed by washing with diethylether, showed two resonance signals in a $1: 1$ ratio in the ${ }^{31} \mathrm{P}$ NMR spectrum at $20.1 \mathrm{ppm}$ (POMe) and $-67.3 \mathrm{ppm}$ (anionic P), but no ${ }^{3} J_{(\mathrm{P}, \mathrm{P})}$ coupling (Table 1). Further confirmation for $\mathbf{3}$ was obtained from NMR and MS experiments as well as elemental analysis. DFT calculations, performed on $\mathrm{N}$-Me model compounds, ${ }^{14}$ reveal that the aro-matic character of the middle ring in $\mathbf{3}^{\prime}$ is lower $(\mathrm{NICS}(0)=-4.9)$ than in $1^{\prime 14}\left((\mathrm{NICS}(0)=-8.1)\right.$ or $2^{\prime}$ $(\operatorname{NICS}(0)=-10.0)$; nevertheless some - apparently hyperconjugative - cyclic conjugation is still operative. In contrast, the outer rings retain high aromatic character $(\operatorname{NICS}(0)=-11.1)$.

To access the first example of an anionic P-functional bis (NHC), deprotonation of the bis(imidazolium) salt 3 was performed in THF using two equivalents of KHMDS (Scheme 2).

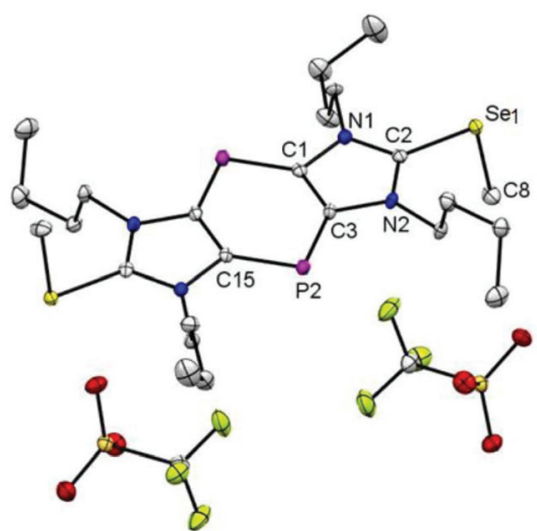

Fig. 2 Molecular structure of compound 2 (ellipsoids at the $50 \%$ probability-substituted level); hydrogen atoms are omitted for clarity. Selected bond lengths [Å] and angles [ $\left.{ }^{\circ}\right]$ : C2-Se1 1.896(4), Se1-C8 1.952 (4), C2-N2 1.339(5), N2-C3 1.397(5), C3-P2 1.736(4), C1-C3 1.412(6); N1-C2-N2 108.8(3), C3-P2-C15 96.3(2).

Table $1{ }^{31} \mathrm{P}\left\{{ }^{1} \mathrm{H}\right\}$ and ${ }^{13} \mathrm{C}\left\{{ }^{1} \mathrm{H}\right\}$ NMR data for $3,4,5^{\text {cis/trans }}(1: 0.3)$ and $6^{\text {cis/ }}$ trans $(1: 0.3)$

\begin{tabular}{lll}
\hline & $\delta\left({ }^{31} \mathrm{P}\right) / \mathrm{ppm}\left(\mathrm{CD}_{2} \mathrm{Cl}_{2}\right)$ & $\delta\left({ }^{13} \mathrm{C}\right) / \mathrm{ppm}\left(\mathrm{CD}_{2} \mathrm{Cl}_{2}\right)^{b}$ \\
\hline $\mathbf{3}$ & $20.1(\mathrm{~s}),-67.3(\mathrm{~s})$ & $137.3\left(\mathrm{~d},{ }^{3} J_{\mathrm{P}, \mathrm{C}}=4.5 \mathrm{~Hz}\right)$ \\
$\mathbf{4}^{a}$ & $25.2(\mathrm{~s}),-74.8(\mathrm{~s})$ & $208.8(\mathrm{br})$ \\
$\mathbf{5}^{\text {cis/trans }}$ & $\delta=-71.58\left(\mathrm{~d},{ }^{3} J_{\mathrm{P}, \mathrm{H}}=5.2 \mathrm{~Hz}\right),-66.23$ & $142.4(\mathrm{br}), 143.37(\mathrm{br})$ \\
& $\left(\mathrm{d}, J_{\mathrm{P}, \mathrm{H}}=4.9 \mathrm{~Hz}\right), 39.57(\mathrm{br}), 43.7(\mathrm{br})$ & \\
$\mathbf{6}^{\text {cis/trans }}$ & $\delta=-74.0\left(\mathrm{~d},{ }^{2} J_{\mathrm{P}, \mathrm{H}}=4.8 \mathrm{~Hz}\right),-68.6$ & $224.2,223.8$, \\
& $\left(\mathrm{d},{ }^{2} J_{\mathrm{P}, \mathrm{H}}=3.7 \mathrm{~Hz}\right), 37.2\left(\mathrm{~d},{ }^{3} J_{\mathrm{P}, \mathrm{H}}=\right.$ & $\left(\mathrm{t},{ }^{3} J_{\mathrm{P}, \mathrm{C}}=2.7 \mathrm{~Hz}\right)$ \\
& $4.6 \mathrm{~Hz}), 41.3\left(\mathrm{~d},{ }^{3} J_{\mathrm{P}, \mathrm{H}}=3.8 \mathrm{~Hz}\right)$ &
\end{tabular}

${ }^{a}$ In case of 4 and $6^{\text {cis/trans }}(1: 0.4)$ THF-d8. ${ }^{b} C^{2}$ carbon.

After extraction with THF/diethyl ether $(1: 1.5)$, compound 4 was isolated as a dark orange solid which has two resonances in its ${ }^{31} \mathrm{P}$ NMR spectrum at $25.2 \mathrm{ppm}$ (P-OMe) and $-74.8 \mathrm{ppm}$ (anionic P). The ${ }^{1} \mathrm{H}$-NMR spectrum confirms the absence of the $C^{2}-\mathrm{H}$ proton and the ${ }^{13} \mathrm{C}\left\{{ }^{1} \mathrm{H}\right\}$ NMR spectrum a broad resonance at $208.8 \mathrm{ppm}$ assigned to the $C^{2}$ atom of dicarbene 4 . The proposed constitution of $\mathbf{4}$ is also supported by HR-MS (negative ESI; exp. 449.2605 vs. calc. 449.2607). In order to establish the stability of the carbene $\mathbf{4}$, an isodesmic reaction (see ESI $\dagger$ ) yields $113.3 \mathrm{kcal} \mathrm{mol}{ }^{-1}$ stabilization for $4^{\prime} .{ }^{14}$ This is very similar to our earlier reported $111.1 \mathrm{kcal} \mathrm{mol}^{-1}$ value ${ }^{12}$ for III ( $\mathrm{R}: \mathrm{Me}, \mathrm{R}^{\prime}$ : cis- $\mathrm{NEt}_{2}$ ), indicating that the carbene character
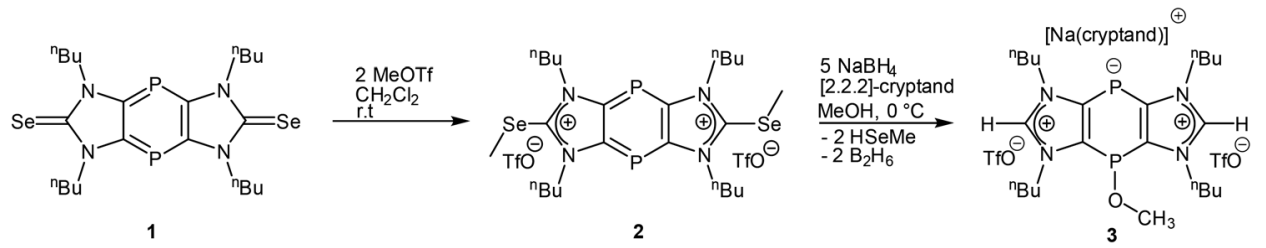

Scheme 1 Synthesis of doubly Se-methylated salt 2 and bis(imidazolium) salt 3 starting from tricyclic diselone 1. 


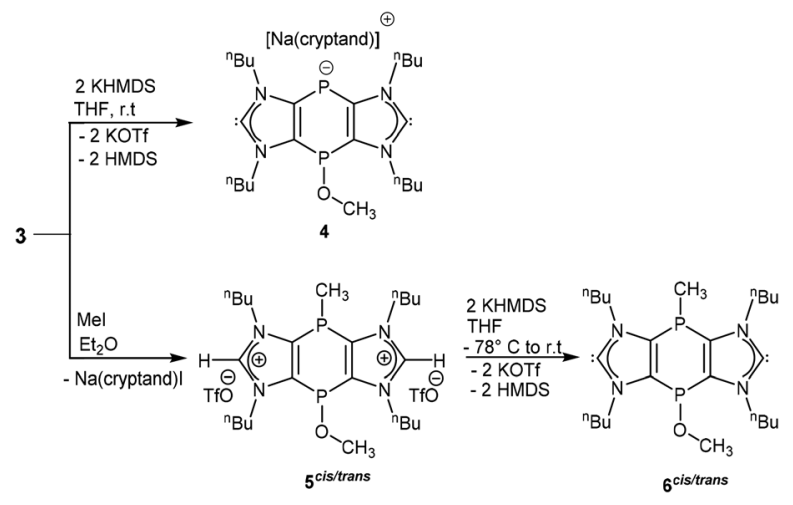

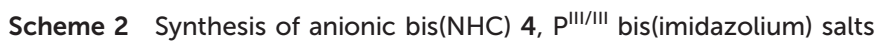
$5^{\text {cis/trans }}(1: 0.3)$ and mixed substituted bis(NHCs) $6^{\text {cis/trans }}(1: 0.3)$.

in the anionic tri-cycle is virtually unchanged. Compared to $\mathbf{3}^{\prime}$, the aromaticity of the middle ring is slightly higher $(\operatorname{NICS}(0)=$ $-5.5)$, while that of the outer rings is lower $(\operatorname{NICS}(0)=-9.0)$, as is usual for NHCs if compared to imidazolium salts. ${ }^{15}$

\section{Formation of mixed substituted $\mathrm{P}^{\mathrm{II} / \mathrm{III}}$ bridged bis(NHCs) $6^{\text {cis/trans }}$}

We then targeted to use the P-anionic functionality to access bis(NHCs) with a mixed P-substitution pattern. Therefore, 3 was treated with $\mathrm{MeI}$ in diethyl ether at $-80{ }^{\circ} \mathrm{C}$ which resulted in a clean formation of bis(imidazolium) salt $5^{\text {cis/trans }}$ with an isomeric ratio of $1: 0.3$ (signals not assigned) (Scheme 2). The ${ }^{31} \mathrm{P}\left\{{ }^{1} \mathrm{H}\right\}$ NMR spectrum of the reaction mixture showed two sets of signals for two isomers at $\delta\left(\mathrm{P}-\mathrm{CH}_{3}\right)=-71.6\left(\mathrm{~d},{ }^{3} J_{\mathrm{P}, \mathrm{H}}=\right.$ $5.0 \mathrm{~Hz}),-66.2\left(\mathrm{~d},{ }^{3} J_{\mathrm{P}, \mathrm{H}}=5.0 \mathrm{~Hz}\right)$ and $\delta\left(\mathrm{P}-\mathrm{OCH}_{3}\right)=39.6(\mathrm{br})$, 43.7 (br) (ratio $1: 0.4)$. The isolated mixture of $5^{\text {cis/trans }}(1: 0.3)$ was subsequently deprotonated using two equiv. of KHMDS in THF to afford the mixed-substituted bis(NHCs) $\mathbf{6}^{\text {cis/trans }}$ (ratio $1: 0.3)$.

Clear evidence for the latter came from the ${ }^{1} \mathrm{H}$ NMR spectrum of this mixture, since the former $C^{2}-\mathrm{H}$ signal $(\delta=9.47(\mathrm{t}$, ${ }^{3} J_{\mathrm{P}, \mathrm{H}}=3.03 \mathrm{~Hz}$ ), $\left.9.56(\mathrm{br})\right)$ of $5^{\text {cis/trans }}$ were absent. This was further supported by the ${ }^{13} \mathrm{C}\left\{{ }^{1} \mathrm{H}\right\}$ NMR spectrum as the characteristic downfield signals for the $C^{2}$-nuclei were found (Table 1), revealing the formation of the bis(NHCs) $6^{\text {cis/trans }}$ (ratio $1: 0.3$ ). $\mathbf{6}^{\text {trans }}$ and $\mathbf{6}^{\text {cis }}$ are computed to have high stability (the isodesmic reaction energies are 108.8 for $\mathbf{6}^{\text {trans } 14}$ and $108.6 \mathrm{kcal} \mathrm{mol}^{-1}$ for $\mathbf{6}^{\text {'is }}$ ). The aromatic character of the middle ring is significantly lower $(\operatorname{NICS}(0)=-0.1)$, indicating that when both phosphorus centres are saturated the central ring loses its aromaticity, whilst that of the outer rings $(\operatorname{NICS}(0)=-9.7)$ remains high .

Initial coordination chemistry experiments were undertaken to explore the reactivity of tricyclic bis(imidazolium) salt 3. Thus, reaction with a half equiv. of $[\mathrm{Rh}(\operatorname{cod}) \mathrm{Cl}]_{2}$ affords exclusively the mono rhodium(I) complex 7 (Scheme 3). The coordination of 3 to the $\mathrm{Rh}(\mathrm{cod}) \mathrm{Cl}$ fragment is confirmed by the ${ }^{31} \mathrm{P}$ NMR spectrum as resonances of 7 appeared at highfield (-70.6 (s, anionic P) and 47.5 (d) ppm) having a rhodium-phosphorus coupling of ${ }^{1} J_{\mathrm{Rh}, \mathrm{P}}=192.4 \mathrm{~Hz}$, assigned

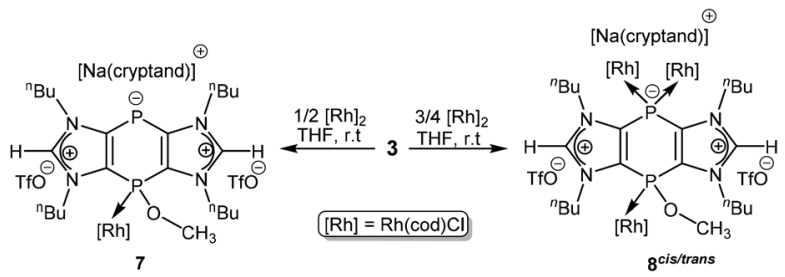

Scheme 3 Synthesis of mononuclear rhodium complex 7 and trinuclear rhodium complexes $8^{\text {cis/trans }}(1: 0.7)$.

to the neutral phosphorus atom. This coordination mode is surprising since the HOMO of $\mathbf{3}^{\prime}$ is located at the dicoordinate (anionic) phosphorus atom, and the involved tricoordinate phosphorus, largely representing HOMO-1, is lower in energy by as much as $1.9 \mathrm{eV}$ (see ESI†). Nevertheless, our calculations on the isomeric complexes of $7^{\prime}$ showed that the favoured coordination site is indeed the tricoordinate phosphorus, $7^{\prime}$ being more stable than the possible isomers (cis and trans) by more than $5 \mathrm{kcal} \mathrm{mol}^{-1}$ (see ESI $\dagger$ ). To examine how many $\mathrm{Rh}(\mathrm{I})$ fragments could be coordinated to $\mathbf{3}$, it was then treated with 1.5 equiv. of the rhodium dimer which afforded selectively an isomeric mixture of trinuclear phosphanido complexes $\mathbf{8}^{\text {cis/ }}$ trans (ratio 0.9:1) (Scheme 3). Upon coordination, two sets of signals are present in the ${ }^{31} \mathrm{P}$ NMR spectrum at $65.0\left(\mathrm{~d},{ }^{1} J_{\mathrm{Rh}, \mathrm{P}}=\right.$ $195.6 \mathrm{~Hz})($ minor $) / 64.1\left(\mathrm{dd},{ }^{1} J_{\mathrm{Rh}, \mathrm{P}}=200.1 \mathrm{~Hz},{ }^{3} J_{\mathrm{P}, \mathrm{P}}=5.3 \mathrm{~Hz}\right)$ (major) and $-120.3\left(\mathrm{t} \mathrm{br},{ }^{1} J_{\mathrm{Rh}, \mathrm{P}}=126.9 \mathrm{~Hz}\right)($ major $) /-123.4(\mathrm{t}$, ${ }^{1} J_{\mathrm{Rh}, \mathrm{P}}=126.9 \mathrm{~Hz}$ ) (minor).

\section{Cyclic voltametric studies supported by DFT calculations}

The electrochemical properties of bis(NHCs) 4 and $6^{\text {cis/trans }}$ $(1: 0.3)$ were investigated by cyclic voltammetry (CV) in THF $\left(0.2 \mathrm{M}\left[n \mathrm{Bu}_{4} \mathrm{~N}\right]\left[\mathrm{PF}_{6}\right]\right)$ at gold ceramic screen printed electrodes (Au CSPE) in an Ar-filled glove box. Voltammetric data were measured on solutions containing $1.0 \mathrm{mM}$ analyte and representative CVs are presented in Fig. 3 (and in greater detail in the ESI $\dagger$ ). The observed behaviour of $6^{\text {cis/trans }}$ (Fig. $3 \mathrm{~b}$ ) is reminiscent of dicarbenes III $\left(\mathrm{R}_{\mathrm{n}}=\mathrm{P}^{\mathrm{III}} \mathrm{NEt}_{2}\right)^{12}$ and we therefore start the analysis here.

There are a series of facile, chemically irreversible oxidations with anodic peak potentials $E_{\mathrm{p}}^{\mathrm{a} 1}=-0.29 \mathrm{~V}, E_{\mathrm{p}}^{\mathrm{a} 2}=-0.07$ $\mathrm{V}$ and $E_{\mathrm{p}}^{\mathrm{a} 3}=+0.65$. The processes are nonetheless repeatable and stable to scanning first in anodic or cathodic directions, and continue right up to the anodic potential limit at around $+1.0 \mathrm{~V}$. This is consistent with oxidations involving the carbene $\sigma(\mathrm{p})$-centred HOMO and HOMO-1 as determined from B3LYP/6-31+G*//M06-2X/6-31+G* computations undertaken on the model structures $6^{\text {'is/trans } 15}$ (Fig. 4). The more positive first oxidations $E_{\mathrm{p}}^{\mathrm{a} 1}=-0.29 \mathrm{~V}$ for $6^{\text {cis/trans }}$ compared to III $\left(\mathrm{R}_{\mathrm{n}}=\right.$ $\mathrm{P}^{\mathrm{III}} \mathrm{NEt}_{2}$ ), for which $E_{\mathrm{p}}^{\mathrm{a} 1}=-0.61 \mathrm{~V}$ (ref. 12) reflect the lower lying HOMO energies of $-5.93 /-5.92 \mathrm{eV}$ of the former versus $-5.78 /-5.77 \mathrm{eV}$ for the latter; as before, we are not able to identify separate $\mathrm{CV}$ processes for the two geometrical isomers that are known to co-exist in solution. The true electrochemical reductions for the two types of $\mathrm{P}^{\mathrm{III}}$ dicarbenes both occur at 

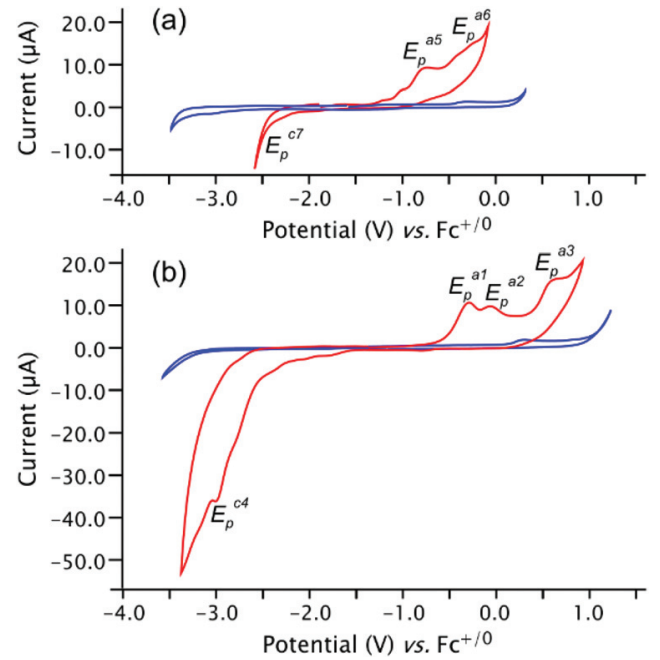

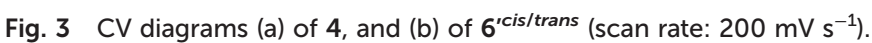
In each case, the blue trace indicates the solvent/electrolyte background $(0.2 \mathrm{M})\left[n \mathrm{Bu}_{4} \mathrm{~N}\right]\left[\mathrm{PF}_{6}\right]$ in $(\mathrm{THF})$, and the red that from a $1.0 \mathrm{mM}$ solution of analyte.

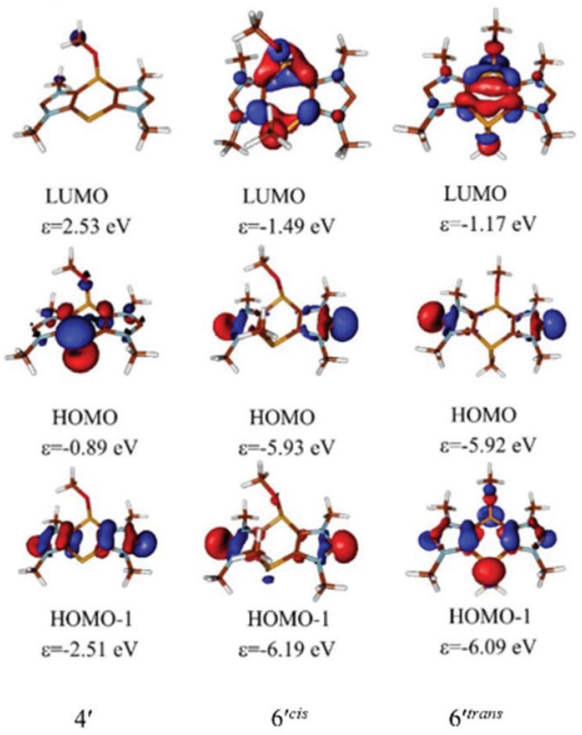

Fig. 4 FMO topologies and energies for the model $\left(\mathrm{R}=\mathrm{CH}_{3}\right)$ calculated structures of $4^{\prime}, 6^{\prime}$ cis and $6^{\text {trans }}$ at the B3LYP/6-31+G*//M06-2X/6$31+G *$ level of theory (PCM solvent model).

very low potentials (less than $-3.5 \mathrm{~V}$ ) and probably cannot be measured accurately; the shoulder on the main reduction wave in the CVs (e.g. $\left.E_{\mathrm{p}}^{\mathrm{c} 1}\right)$ are likely from breakdown products of the IRR oxidations (see ESI $\dagger$ for further explanations).

In contrast to this established behaviour of the diphosphinine dicarbenes, the CVs measured on $\mathbf{4}$ are less well defined although the onset of oxidation is definitely lower in potential than in $6^{\text {cis/trans }}$ with $E_{\mathrm{p}}^{\mathrm{a} 5}=-0.74 \mathrm{~V}$ (Fig. 3a). The computed HOMO of model system $\mathbf{4}^{\prime}$ is very different (Fig. 4) and is essentially localized at the anionic $\mathrm{P}$ atom, and, as expected for an anion, is also at a much higher computed energy $(-0.89$

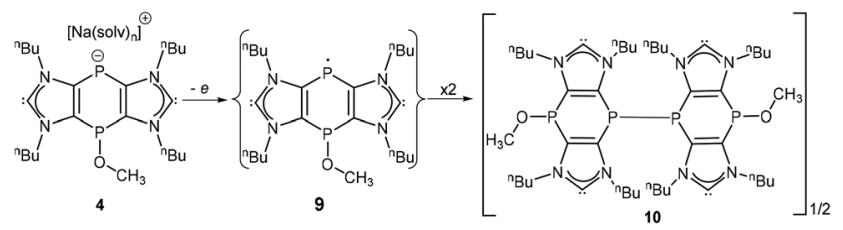

Scheme 4 One electron reduction of 4 to neutral 9 with rapid dimerization to 10 .

eV). Experimentally, the onset of oxidation does not have the expected well-separated peak for a first $1 e$ oxidation of such a localized MO, followed by further processes after a considerable gap.

A plausible explanation for the observed behaviour is that $1 e$ oxidation gives $\mathrm{P}$-centred radical bis(NHC) 9 which rapidly dimerizes to give tetrakis NHC 10 (Scheme 4). Related tricyclic dithione P-radicals have been shown to be very short-lived furnishing structurally verified dimers with a P-P bond. ${ }^{16}$ On this view, the remaining processes such as $E_{\mathrm{p}}^{\mathrm{a} 6}=-0.30 \mathrm{~V}$ and $E_{\mathrm{p}}^{\mathrm{c} 1}=$ $-2.5 \mathrm{~V}$ recorded in the CVs of 4 (Fig. 3a) are best under-stood as redox processes of such a tetrakis NHC.

\section{Experimental section}

\section{Experimental details and devices}

All experiments were done under an argon atmosphere, using common Schlenk techniques and dry solvents. Tetrahydrofuran, $n$-pentane and diethyl ether were dried over sodium wire/benzophenone and further purified by subsequent distillation. The precursor for 1, the 1,4-dichloro-1,4dihydro-1,4-diphosphinine, was synthesized using standard protocols. ${ }^{12}$ All NMR spectra were recorded on a Bruker AX-300 spectrometer $\left(300.1 \mathrm{MHz}\right.$ for ${ }^{1} \mathrm{H}, 75.5 \mathrm{MHz}$ for ${ }^{13} \mathrm{C}$, and 121.5 $\mathrm{MHz}$ for ${ }^{31} \mathrm{P}$ ) and pollux-500 (500.1 $\mathrm{MHz}$ for ${ }^{1} \mathrm{H}$, 125.75 MHz for ${ }^{13} \mathrm{C}$, and $500.0 \mathrm{MHz}$ for ${ }^{31} \mathrm{P}$ ) spectrometer. The ${ }^{1} \mathrm{H}$ and ${ }^{13} \mathrm{C}$ NMR spectra were referenced to the residual proton resonances and the ${ }^{13} \mathrm{C}$ NMR signals of the deuterated solvents and ${ }^{31} \mathrm{P}$ to $85 \% \mathrm{H}_{3} \mathrm{PO}_{4}$ as external standard, respectively. Elemental analyses were carried out on a Vario EL gas chromatograph. Melting points were determined in one-side melted off capillaries using a Büchi Type S or a Carl Roth Type MPM-2 apparatus, they are uncorrected Mass spectrometric data were collected on a Kratos MS 50 spectrometer using EI, $70 \mathrm{eV}$. IR spectra of all compounds were recorded on a Thermo IR spectrometer with an attenuated total reflection (ATR) attachment. The X-ray analyses were performed on a Bruker APEX-II CCD or a Bruker X8-KappaApexII type diffractometer at $100(2) \mathrm{K}$. The structures were solved by direct methods refined by full-matrix least-squares technique in anisotropic approximation for non-hydrogen atoms using SHELXS97 and SHELXL97 ${ }^{17}$ program packages. Crystallographic data for the structures reported in this paper have been deposited with the Cambridge Crystallographic Data Centre as supplementary publication no. CCDC 2032731 (1), 2032732 (2). $\dagger$ 


\section{Synthesis of compounds}

1. To a clear solution of 1,4 -bis(diethylamino)-1,4-dihydro-1,4diphosphinine ${ }^{12}(2.5 \mathrm{~g}, 3.5 \mathrm{mmol})$ in dichloromethane, $\mathrm{PCl}_{3}$ (0.61 $\mathrm{mL}, 6.9 \mathrm{mmol}$ ) was added and stirred for 4 hours at $-40{ }^{\circ} \mathrm{C}$. The reaction mixture was then warmed to room temperature and tris(n-butyl)phosphane $(0.34 \mathrm{~mL}, 1.4 \mathrm{mmol})$ was added in a dropwise manner. After 10 minutes stirring, a colour change of the solution from orange to violet was observed. After concentrating the reaction mixture under reduced pressure, the residue was filtered via a silica ${ }^{\circledR}$ bed with diethyl ether and toluene mixture $(1: 1)$. It was then dried under reduced pressure $\left(6 \times 10^{-3}\right.$ mbar and washed with $n$-pentane $(3 \times 10 \mathrm{~mL})$ to get rid of the aminophosphane $\mathrm{Et}_{2} \mathrm{NPCl}_{2}$. Finally, the solution was con-centrated in vacuo $(6 \times$ $\left.10^{-3} \mathrm{mbar}\right)$ to get 1 as pure compound. Yield: $1.2 \mathrm{~g}(2.1 \mathrm{mmol})$ $61 \%$; violet solid. M.p. $223{ }^{\circ} \mathrm{C} .{ }^{1} \mathrm{H}$ NMR (300.1 MHz, $\mathrm{C}_{6} \mathrm{D}_{6}$, $\left.25{ }^{\circ} \mathrm{C}\right): \delta=0.8\left(\mathrm{t}, 12 \mathrm{H},{ }^{3} \mathrm{~J}_{\mathrm{H}, \mathrm{H}}=7.3 \mathrm{~Hz}, \mathrm{NCH}_{2} \mathrm{CH}_{2} \mathrm{CH}_{2} \underline{\mathrm{Me}}\right)$, 1.2-1.4 (m, 8H, $\left.\mathrm{NCH}_{2} \mathrm{CH}_{2} \underline{C H}_{2} \mathrm{Me}\right), \quad 1.8-1.9 \quad(\mathrm{~m}, \quad 8 \mathrm{H}$, $\mathrm{NCH}_{2} \underline{\mathrm{CH}}_{2} \mathrm{CH}_{2} \mathrm{Me}$ ), 4.4-4.4 (m, 8H, N $\left.\underline{C H}_{2} \mathrm{CH}_{2} \mathrm{CH}_{2} \mathrm{Me}\right) .{ }^{13} \mathrm{C}\left\{{ }^{1} \mathrm{H}\right\}$ NMR (75.5 MHz, $\left.\mathrm{C}_{6} \mathrm{D}_{6}, 25^{\circ} \mathrm{C}\right): \delta=13.55$ (s, $\mathrm{NCH}_{2} \mathrm{CH}_{2} \mathrm{CH}_{2} \underline{\mathrm{Me}}$ ), $19.9\left(\mathrm{~s}, \quad \mathrm{NCH}_{2} \mathrm{CH}_{2} \underline{\mathrm{CH}}_{2} \mathrm{Me}\right), 28.9\left(\mathrm{t},{ }^{3} J_{\mathrm{P}, \mathrm{C}}=1.6 \mathrm{~Hz}\right.$, $\left.\mathrm{NCH}_{2} \underline{C H}_{2} \mathrm{CH}_{2} \mathrm{Me}\right), 48.1$ (t, $\left.{ }^{3} J_{\mathrm{P}, \mathrm{C}}=4.6 \mathrm{~Hz}, \mathrm{NCH}_{2} \underline{C H}_{2} \mathrm{CH}_{2} \mathrm{Me}\right)$, $152.2\left(\mathrm{t},{ }^{1} J_{\mathrm{P}, \mathrm{C}}=23.1 \mathrm{~Hz}, \mathrm{P}-\underline{C}\right.$ of the middle ring), $168.32(\mathrm{br}$, $\left.\underline{C}^{2}\right) .{ }^{31} \mathrm{P}\left\{{ }^{1} \mathrm{H}\right\}$ NMR $\left(121.5 \mathrm{MHz}, \mathrm{C}_{6} \mathrm{D}_{6}, 25{ }^{\circ} \mathrm{C}\right): \delta=78.2(\mathrm{~s}) .{ }^{77} \mathrm{Se}$ NMR (57.28 MHz, $\left.\mathrm{CDCl}_{3}\right): 179.4(\mathrm{~s}) . \mathrm{IR}\left[\mathrm{cm}^{-1}\right]: \tilde{\nu}=2998.1(\mathrm{v})$, 2752.8 (m), 2654.0 (m), 1487.0 (s), 1289.1 (s), 1201.5 (s), 1098.2 (m), 964.0 (s). MS (EI, $70 \mathrm{eV}): m / z(\%)=578.0$ (100) [M] $]^{++}, 498.1$ (20) $[\mathrm{M}-\mathrm{Se}]^{\circ+}$. UV-vis $\left(\mathrm{CH}_{2} \mathrm{Cl}_{2}\right): \lambda_{\max }[\mathrm{nm}]$ (abs.): 296 (1.375), 383 (0.156), 554(0.139). EA [\%]: theor./exp. C 45.84/45.64, H 6.30/6.46; N 9.72/9.63.

2. 2 equivalents of trifluoromethyl methylsulfonate $(0.4 \mathrm{~mL}$, $3.4 \mathrm{mmol})$ was added to a solution of $1(1.0 \mathrm{~g}, 1.7 \mathrm{mmol})$ in dichloromethane, at room temperature. The reaction mixture was stirred for 2 hours resulting in a color change from violet to light yellow. After concentrating the reaction mixture under reduced pressure $\left(6 \times 10^{-3} \mathrm{mbar}\right)$, the residue was washed with $n$-pentane $(2 \times 5 \mathrm{~mL})$ to get 2 as pure light yellow solid. Yield $1.4 \mathrm{~g}$ (1.5 mmol) 91\%; light yellow solid. M.p. $96{ }^{\circ} \mathrm{C} .{ }^{1} \mathrm{H}$ NMR $\left(300.1 \mathrm{MHz}, \mathrm{CDCl}_{3}, 25{ }^{\circ} \mathrm{C}\right): 1.04\left(\mathrm{t}, 12 \mathrm{H},{ }^{3} J_{\mathrm{H}, \mathrm{H}}=7.4 \mathrm{~Hz}\right.$, $\left.\mathrm{NCH}_{2} \mathrm{CH}_{2} \mathrm{CH}_{2} \underline{\mathrm{Me}}\right), \quad 1.52-1.62\left(\mathrm{~m}, \quad 8 \mathrm{H}, \quad \mathrm{NCH}_{2} \mathrm{CH}_{2} \underline{\mathrm{CH}}_{2} \mathrm{Me}\right)$, 2.05-2.15 (m, 8H, $\left.\mathrm{NCH}_{2} \underline{\mathrm{CH}}_{2} \mathrm{CH}_{2} \mathrm{Me}\right), 2.8$ (s, 6H, $\left.\mathrm{Se} \underline{\mathrm{Me}}\right)$ 4.89-4.94 (m, 8H, N $\left.\underline{C H}_{2} \mathrm{CH}_{2} \mathrm{CH}_{2} \mathrm{Me}\right) .{ }^{13} \mathrm{C}\left\{{ }^{1} \mathrm{H}\right\} \mathrm{NMR}(75.5 \mathrm{MHz}$, $\left.\mathrm{CDCl}_{3}, 25^{\circ} \mathrm{C}\right): \delta=11.72(\mathrm{~s}, \mathrm{Se} \underline{\mathrm{Me}}), 13.44\left(\mathrm{~s}, \mathrm{NCH}_{2} \mathrm{CH}_{2} \mathrm{CH}_{2} \underline{\mathrm{Me}}\right.$ ), 20.16 (s, $\mathrm{NCH}_{2} \mathrm{CH}_{2} \underline{C}_{2} \mathrm{Me}$ ), 30.73 (s, $\mathrm{NCH}_{2} \underline{C}_{2} \underline{C H}_{2} \mathrm{Me}$ ), 52.18 $\left(\mathrm{s}, \mathrm{NCH}_{2} \underline{\mathrm{CH}}_{2} \mathrm{CH}_{2} \mathrm{Me}\right), 148.84\left(\mathrm{t},{ }^{3} \mathrm{~J}_{\mathrm{P}, \mathrm{C}}=4.6 \mathrm{~Hz}, \mathrm{Se}-\underline{C}^{2}\right), 154.94(\mathrm{t}$, ${ }^{1} J_{\mathrm{P}, \mathrm{C}}=26.1 \mathrm{~Hz}, \mathrm{P}-\underline{C}$ of the middle ring). ${ }^{31} \mathrm{P}$ NMR $(121.5 \mathrm{MHz}$, $\left.\mathrm{CDCl}_{3}, 25{ }^{\circ} \mathrm{C}\right): \delta=119.95(\mathrm{~s}) .{ }^{77} \mathrm{Se} \mathrm{NMR}\left(57.28 \mathrm{MHz}, \mathrm{CDCl}_{3}\right)$ : 138.89 (s). IR $\left[\mathrm{cm}^{-1}\right]: \tilde{\nu}=3009.1(\mathrm{v}), 2992.8(\mathrm{~m}), 2954.0(\mathrm{~m})$, $1623.0(\mathrm{w}), 1529.1(\mathrm{w}), 1461.5(\mathrm{~m}), 1236.2(\mathrm{~m}), 1201.3(\mathrm{w})$, $1075.4(\mathrm{~m}), \quad 1032.2 \quad(\mathrm{v}), \quad 974.0 \quad$ (s). Pos. ESI-MS: $\left[\mathrm{C}_{25} \mathrm{H}_{42} \mathrm{~F}_{3} \mathrm{~N}_{4} \mathrm{O}_{3} \mathrm{P}_{2} \mathrm{SSe}_{2}\right]^{+}$calcd (found) 757.0728 (757.0750). neg. ESI-MS: TfO $^{-}$theor./exp. 148.9(149.5). EA [\%]: theor./exp. C 34.52/34.33, H 4.68/4.71; N 6.19/6.0, S 7.08/6.99.

3. To a solution of $2(1.5 \mathrm{~g}, 1.6 \mathrm{mmol})$ in methanol, 5 equivalents of sodium tetrahydridoborate $(0.3 \mathrm{~g}, 8.2 \mathrm{mmol})$ and one equivalent of [2.2.2]-cryptand was added as solid at $0{ }^{\circ} \mathrm{C}$. The reaction mixture turned to orange-red with strong odour due to a liberation of methylselane (HMeSe). The solution was then concentrated in vacuo $\left(6 \times 10^{-3}\right.$ mbar $)$ after 30 minutes stirring. Extraction was done with dichloromethane followed by washing with diethyl ether $(2 \times 5 \mathrm{~mL})$ to get 3 as pure orange red solid. Yield: $1.2 \mathrm{~g}$ (1.04 mmol) 65\%; red orange solid, M.p. $142{ }^{\circ} \mathrm{C}{ }^{1} \mathrm{H}$ NMR $\left(300.1 \mathrm{MHz}, \mathrm{CD}_{2} \mathrm{Cl}_{2}\right.$, $\left.25{ }^{\circ} \mathrm{C}\right): \delta=1.0\left(\mathrm{t}, 12 \mathrm{H},{ }^{3} J_{\mathrm{H}, \mathrm{H}}=7.3 \mathrm{~Hz}, \mathrm{NCH}_{2} \mathrm{CH}_{2} \mathrm{CH}_{2} \underline{\mathrm{Me}}\right)$, 1.3-1.5 (m, 8H, $\left.\mathrm{NCH}_{2} \mathrm{CH}_{2} \underline{\mathrm{CH}}_{2} \mathrm{Me}\right), \quad 1.9-2.1 \quad(\mathrm{~m}, \quad 8 \mathrm{H}$, $\mathrm{NCH}_{2} \underline{\mathrm{CH}}_{2} \mathrm{CH}_{2} \mathrm{Me}$ ), 2.4 (d, 3H, $\left.{ }^{3} \mathrm{~J}_{\mathrm{P}, \mathrm{H}}=7.3 \mathrm{~Hz}, \mathrm{O}-\underline{\mathrm{Me}}\right) 2.6(\mathrm{t}, 12 \mathrm{H}$, cryptand), 3.6 (t, 12H, cryptand), 3.7 (s, 12H, cryptand), 4.1-4.6 $\left(\mathrm{m}, 8 \mathrm{H}, \underline{N}_{\underline{H}} \underline{H}_{2} \mathrm{CH}_{2} \mathrm{CH}_{2} \mathrm{Me}\right), 8.9\left(\mathrm{t}, 2 \mathrm{H},{ }^{4} \mathrm{~J}_{\mathrm{P}, \mathrm{H}}=1.7 \mathrm{~Hz}, \mathrm{C}^{2}-\underline{H}\right) .{ }^{13} \mathrm{C}$ $\left\{{ }^{1} \mathrm{H}\right\} \quad \mathrm{NMR}\left(75.5 \mathrm{MHz}, \mathrm{CD}_{2} \mathrm{Cl}_{2}, \quad 25{ }^{\circ} \mathrm{C}\right): \delta=13.2 \quad(\mathrm{~s}$, $\mathrm{NCH}_{2} \mathrm{CH}_{2} \mathrm{CH}_{2} \underline{\mathrm{Me}}$ ), 19.6 (s, $\left.\mathrm{NCH}_{2} \mathrm{CH}_{2} \underline{\mathrm{CH}}_{2} \mathrm{Me}\right), 30.2$ (s, $\mathrm{NCH}_{2} \underline{\mathrm{C}}_{2} \mathrm{CH}_{2} \mathrm{Me}$ ), 47.8 (s, $\underline{\mathrm{N}}_{\underline{H}_{2}} \mathrm{CH}_{2} \mathrm{CH}_{2} \mathrm{Me}$ ), 67.5 (s, cryptand), 68.5 (s, cryptand), 120.9 (d, $\left.{ }^{2} J_{\mathrm{P}, \mathrm{C}}=7.3 \mathrm{~Hz}, O-\underline{C}_{3}\right), 121.7$

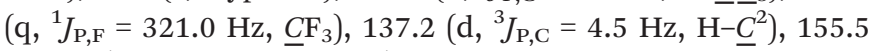
$\left(\mathrm{ddd},{ }^{1 / 2} J_{\mathrm{P}, \mathrm{C}}=47.0 \mathrm{~Hz}, \underline{C}^{4 / 5}\right) .{ }^{31} \mathrm{P} \mathrm{NMR}\left(121.5 \mathrm{MHz}, \mathrm{CD}_{2} \mathrm{Cl}_{2}\right.$, $\left.25{ }^{\circ} \mathrm{C}\right): \delta=20.12(\mathrm{P}-\mathrm{OMe}),-67.34$ (anion P). IR $\left[\mathrm{cm}^{-1}\right]: \tilde{\nu}=$ 2984 (v), 2921.8 (m), 2894.0 (m), 1542.0 (w), 498.1 (w), 1423.5 (m), 1246.2 (m), 1206.3 (w), 1012.4 (m), 968.4 (s). Pos. ESI-MS: $m / z(\%)=451.3(100)[\mathrm{M}]^{+}, 399.1$ (97) $\left[\mathrm{Na}\left(\mathrm{C}_{18} \mathrm{~N}_{2} \mathrm{H}_{36} \mathrm{O}_{6}\right)\right]^{\bullet+}$. HRMS: $\left[\mathrm{C}_{23} \mathrm{H}_{41} \mathrm{~N}_{4} \mathrm{OP}_{2}\right]^{+}$theor./exp. 451.2750 (451.2754). UV/vis $\left(\mathrm{CH}_{2} \mathrm{Cl}_{2}\right): \lambda[\mathrm{nm}]$ (abs.): 346 (0.791). EA [\%]: theor./exp. C 44.94/ 45.12, H 6.75/6.64; N 7.31/6.74, S 5.58/5.68.

4. A solution of potassium hexamethyldisilazide (KHMDS) $(0.7 \mathrm{~g}, 3.5 \mathrm{mmol})$ in $5 \mathrm{~mL}$ of THF was added dropwise to a solution of $3(2 \mathrm{~g}, 1.7 \mathrm{mmol})$ in $10 \mathrm{~mL}$ of THF at room temperature. After $1 \mathrm{~h}$, all volatiles were removed in vacuo $\left(6 \times 10^{-3}\right.$ mbar). The residue was washed (twice) with diethyl ether followed by extraction with mixture of THF and diethyl ether $(1: 1.5)$ to remove the potassium triflate. After concentrating the extracted solution, the product 4 was obtained as dark orange solid. Yield: $1.1 \mathrm{~g}$ (1.3 mmol) 76\%; Dark orange. M. p. $207{ }^{\circ}$ C. ${ }^{1} \mathrm{H}$ NMR $\left(500.1 \mathrm{MHz}, \mathrm{THF}, 25{ }^{\circ} \mathrm{C}\right): \delta=0.9(\mathrm{t}, 12 \mathrm{H}$, $\left.{ }^{3} J_{\mathrm{H}, \mathrm{H}}=6.5 \mathrm{~Hz}, \quad \mathrm{NCH}_{2} \mathrm{CH}_{2} \mathrm{CH}_{2} \underline{\mathrm{Me}}\right), \quad 1.2-1.3(\mathrm{~m}, 8 \mathrm{H}$, $\mathrm{NCH}_{2} \mathrm{CH}_{2} \underline{C}_{2} \mathrm{Me}$ ), 1.8-1.9 (m, 8H, $\mathrm{NCH}_{2} \underline{C H}_{2} \mathrm{CH}_{2} \mathrm{Me}$ ), 2.1 (d, $\left.3 \mathrm{H},{ }^{4} J_{\mathrm{P}, \mathrm{H}}=6.3 \mathrm{~Hz}, \mathrm{O}-\underline{\mathrm{Me}}\right) 2.5(\mathrm{t}, 12 \mathrm{H}$, cryptand), $3.5(\mathrm{t}, 12 \mathrm{H}$, cryptand), $3.6(\mathrm{~s}, 12 \mathrm{H}$, cryptand), 3.8-4.5 (m, $8 \mathrm{H}$, $\left.\mathrm{N} \underline{C H}_{2} \mathrm{CH}_{2} \mathrm{CH}_{2} \mathrm{Me}\right) .{ }^{13} \mathrm{C}\left\{{ }^{1} \mathrm{H}\right\} \mathrm{NMR}\left(75.5 \mathrm{MHz}, \mathrm{THF}-\mathrm{d}_{8}, 25{ }^{\circ} \mathrm{C}\right): \delta$ $=13.5\left(\mathrm{~s}, \mathrm{NCH}_{2} \mathrm{CH}_{2} \mathrm{CH}_{2} \underline{\mathrm{Me}}\right), 20.1\left(\mathrm{~s}, \mathrm{NCH}_{2} \mathrm{CH}_{2} \underline{\mathrm{C}}_{2} \mathrm{Me}\right), 32.3(\mathrm{~s}$, $\mathrm{NCH}_{2} \underline{\mathrm{C}}_{2} \mathrm{CH}_{2} \mathrm{Me}$ ), 47.5 (s, $\underline{\mathrm{N}}_{\mathrm{H}_{2}} \mathrm{CH}_{2} \mathrm{CH}_{2} \mathrm{Me}$ ), 67.6 (s, cryptand), 70.4 (s, cryptand), 120.2 (d, $\left.{ }^{2} J_{\mathrm{P}, \mathrm{C}}=7.5 \mathrm{~Hz}, O-\underline{C H}_{3}\right), 154.2$ $\left(\mathrm{d},{ }^{1 / 2} J_{\mathrm{P}, \mathrm{C}}=43.9 \mathrm{~Hz}, \underline{C}^{4 / 5}\right), 215.5\left(\mathrm{~d}, J_{\mathrm{P}, \mathrm{C}}=2.7, \underline{C}^{2}\right) .{ }^{-1} \mathrm{P} \mathrm{NMR}$ (500.0 MHz, THF-d ${ }_{8}, 25{ }^{\circ} \mathrm{C}$ ): $\delta=25.15$ (P-OMe), -74.78 (anion P). IR $\left[\mathrm{cm}^{-1}\right]: \tilde{\nu}=3191.2(\mathrm{w}), 3045.0(\mathrm{~m}), 2975.7(\mathrm{~m}), 1623.4$ (m), $1436.3(\mathrm{~m}), 1375.3(\mathrm{~m}), 1245.7$ (s), $1184.8(\mathrm{~s}), 1016.5(\mathrm{~s})$, 968.5 (s). Neg. ESI-MS: $m / z(\%)=449.261$ (15) [M] $]^{+}$, HRMS: $\left[\mathrm{C}_{23} \mathrm{H}_{39} \mathrm{~N}_{4} \mathrm{OP}_{2}\right]^{-}$theor./exp. 449.2605 (449.2608). UV/vis (THF): $\lambda[\mathrm{nm}]$ (abs.): 407 (0.517).

$5^{\text {cis/trans }}$. To a suspension of $3(2.5 \mathrm{~g}, 2.1 \mathrm{mmol})$ in $50 \mathrm{~mL}$ of diethyl ether, methyl iodide $(1.35 \mathrm{~mL}, 2.1 \mathrm{mmol})$ was added dropwise at $-80{ }^{\circ} \mathrm{C}$. The reaction mixture was stirred for 18 hours and warmed to room temperature. All volatiles were removed in vacuo $\left(6 \times 10^{-3}\right.$ mbar $)$. Residue was extracted with 
dichloromethane followed by washing (twice) with diethyl ether. The solvent was removed under vacuum $\left(6 \times 10^{-3} \mathrm{mbar}\right)$ which resulted in a pure colorless liquid. Yield: $1.2 \mathrm{~g}$ (1.6 mmol) 75\%; colorless liquid. Ratio of two isomers $1: 0.3$. M.p. - (liquid at r.t.). ${ }^{1} \mathrm{H} \mathrm{NMR}\left(300.1 \mathrm{MHz}, \mathrm{CD}_{2} \mathrm{Cl}_{2}, 25{ }^{\circ} \mathrm{C}\right): \delta=$ $1.04,1.06\left(\mathrm{t}, 12 \mathrm{H},{ }^{3} J_{\mathrm{H}, \mathrm{H}}=7.4 \mathrm{~Hz}, \mathrm{NCH}_{2} \mathrm{CH}_{2} \mathrm{CH}_{2} \underline{\mathrm{Me}}\right), 1.41-1.54$ (m, 8H, $\mathrm{PCH}_{2} \mathrm{CH}_{2} \underline{\mathrm{CH}}_{2} \mathrm{Me}$ ), 1.67 (d, ${ }^{2} J_{\mathrm{P}, \mathrm{H}}=5.2 \mathrm{~Hz}, \underline{P}-\underline{\mathrm{Me}}$ ), 1.87 $\left(\mathrm{d},{ }^{2} J_{\mathrm{P}, \mathrm{H}}=6.8 \mathrm{~Hz}, \underline{\mathrm{O}}-\underline{\mathrm{Me}}\right) ; 1.92-2.11\left(\mathrm{~m}, 8 \mathrm{H}, \mathrm{NCH}_{2} \underline{\mathrm{CH}}_{2} \mathrm{CH}_{2} \mathrm{Me}\right.$, 4.28-4.57 (m, 8H, $\left.\underline{\mathrm{N}}_{\underline{H}_{2}} \mathrm{CH}_{2} \mathrm{CH}_{2} \mathrm{Me}\right), 9.47$ (t, $2 \mathrm{H},{ }^{3} J_{\mathrm{P}, \mathrm{H}}=3.03$ $\mathrm{Hz}, \mathrm{C}^{2}-\underline{H}$ ), 9.56 (brs, $\mathrm{C}^{2}-\underline{H}$ ) 2nd isomer. ${ }^{13} \mathrm{C}\left\{{ }^{1} \mathrm{H}\right\} \quad \mathrm{NMR}$ $\left(75.5 \mathrm{MHz}, \quad \mathrm{CD}_{2} \mathrm{Cl}_{2}, \quad 25{ }^{\circ} \mathrm{C}\right): \quad \delta=13.08,13.10 \quad(\mathrm{~s}$, $\mathrm{NCH}_{2} \mathrm{CH}_{2} \mathrm{CH}_{2} \underline{M e}$ of two isomers), 19.52 (br, $\underline{P}-\underline{M e}$ ), 19.68 (s, $\mathrm{NCH}_{2} \mathrm{CH}_{2} \underline{\mathrm{CH}}_{2} \mathrm{Me}$ ), 29.68 (br, $\mathrm{NCH}_{2} \underline{\mathrm{CH}}_{2} \mathrm{CH}_{2} \mathrm{Me}$ ), 31.78 (d, ${ }^{3} J_{\mathrm{P}, \mathrm{C}}$ $\left.=2.6 \mathrm{~Hz}, \mathrm{NCH}_{2} \underline{\mathrm{CH}}_{2} \mathrm{CH}_{2} \mathrm{Me}\right), 32.23\left(\mathrm{~d},{ }^{3} J_{\mathrm{P}, \mathrm{C}}=2.4 \mathrm{~Hz}\right.$, $\mathrm{NCH}_{2} \underline{\mathrm{CH}}_{2} \mathrm{CH}_{2} \mathrm{Me}$ ) (2nd isomer), 49.13 (ddd, ${ }^{3} J_{\mathrm{P}, \mathrm{C}}=9.1 \mathrm{~Hz}$, $\mathrm{N} \underline{C H}_{2} \mathrm{CH}_{2} \mathrm{CH}_{2} \mathrm{Me}$ ), 49.96 (ddd, ${ }^{3} \mathrm{~J}_{\mathrm{P}, \mathrm{C}}=8.2 \mathrm{~Hz}, \underline{N C}_{\mathrm{H}_{2}} \mathrm{CH}_{2} \mathrm{CH}_{2} \mathrm{Me}$ ) (2nd isomer), 122.84 (q, $\left.{ }^{1} J_{\mathrm{P}, \mathrm{F}}=319.5 \mathrm{~Hz}, \underline{C F}_{3}\right), 131.54\left(\mathrm{~d},{ }^{2} J_{\mathrm{P}, \mathrm{C}}=\right.$ $9.5 \mathrm{~Hz}, \mathrm{O}-\underline{\mathrm{CH}}_{3}$ ), 135.38 (ddd, ${ }^{1 / 2} J_{\mathrm{P}, \mathrm{C}}=3.7 \mathrm{~Hz}, \underline{P}-\underline{C}$ of the middle ring), $135.72\left(\mathrm{t},{ }^{1 / 2} J_{\mathrm{P}, \mathrm{C}}=3.0 \mathrm{~Hz}, P-\underline{C}\right.$ of the middle ring) (2nd isomer), 142.38 (br, H-C $\left.\underline{C}^{2}\right), 143.37\left(\mathrm{br}, \mathrm{H}-\underline{C}^{2}\right)$ 2nd isomer. ${ }^{31} \mathrm{P}$ $\operatorname{NMR}\left(500.0 \mathrm{MHz}, \mathrm{CD}_{2} \mathrm{Cl}_{2}, 25^{\circ} \mathrm{C}\right): \delta=-71.58\left(\mathrm{~d},{ }^{3} J_{\mathrm{P}, \mathrm{H}}=5.2 \mathrm{~Hz}\right.$, $P-\underline{M e}$ ), $-66.23\left(\mathrm{~d},{ }^{3} J_{\mathrm{P}, \mathrm{H}}=4.9 \mathrm{~Hz}, P-\underline{M e}\right) ; 39.57$ (br, P-OMe) \& 43.7 (br, $P-O M e)$. IR $\left[\mathrm{cm}^{-1}\right]: \tilde{\nu}=3204.7(\mathrm{~m}), 3145(\mathrm{~m}), 2975.5$ (w), $2768.8(\mathrm{~m}), 1534.3(\mathrm{w}), 1445.3(\mathrm{~s}), 1317.7(\mathrm{~m}), 1206.8(\mathrm{~m})$, 1046.9 (m), 1009.5 (s), 921.5 (s). Pos. ESI-MS: $m / z(\%)=615.251$ (54) $[\mathrm{M}-\mathrm{TfO}]^{+}$; HRMS: $\left[\mathrm{C}_{25} \mathrm{H}_{44} \mathrm{~F}_{3} \mathrm{~N}_{4} \mathrm{O}_{4} \mathrm{P}_{2} \mathrm{~S}\right]^{+}$theor./ exp. 615.2505 (615.2511). EA [\%]: theor./exp. C 40.84/40.53, H 5.80/5.93, N 7.33/7.36.

$6^{\text {cis/trans }}$. A solution of potassium hexamethyldisilazide (KHMDS) (1.04 g, $5.2 \mathrm{mmol}$ ) in $5 \mathrm{~mL}$ of THF was added dropwise to a solution of $5^{\text {cis/trans }}(2.0 \mathrm{~g}, 2.6 \mathrm{mmol})$ in $10 \mathrm{~mL}$ of THF at room temperature. After $1 \mathrm{~h}$, all volatiles were removed in vacuo $\left(6 \times 10^{-3}\right.$ mbar $)$. Residue was extracted with diethyl ether to remove potassium triflate using filtering cannulation. After concentrating the extracted solution, the product $\mathbf{6}^{\text {cis/trans }}$ was obtained as yellow liquid. Yield: $0.92 \mathrm{~g}$ (1.9 mmol) 76\%; (ratio of two isomers $1: 0.30$ ). M.p. - (liquid at r.t.) ${ }^{1} \mathrm{H}$ NMR $\left(500.1 \mathrm{MHz}\right.$, THF-d8, $\left.25{ }^{\circ} \mathrm{C}\right): \delta=0.8,1.1\left(\mathrm{t}, 12 \mathrm{H},{ }^{3} J_{\mathrm{H}, \mathrm{H}}=7.1 \mathrm{~Hz}\right.$, $\mathrm{NCH}_{2} \mathrm{CH}_{2} \mathrm{CH}_{2} \underline{\mathrm{Me}}$ ), $1.2\left(\mathrm{~d},{ }^{2} J_{\mathrm{P}, \mathrm{H}}=5.3 \mathrm{~Hz}, \underline{P}-\underline{\mathrm{Me}}\right), 1.2-1.4(\mathrm{~m}, 8 \mathrm{H}$, $\mathrm{PCH}_{2} \mathrm{CH}_{2} \underline{\mathrm{C}}_{2} \mathrm{Me}$ ), 1.9-2.1 (m, 8H, $\mathrm{NCH}_{2} \underline{C H}_{2} \mathrm{CH}_{2} \mathrm{Me}$ ), 2.7 (d, $\left.{ }^{2} J_{\mathrm{P}, \mathrm{H}}=7.2 \mathrm{~Hz}, \underline{\mathrm{O}}-\underline{\mathrm{Me}}\right), 3.9-4.2\left(\mathrm{~m}, 8 \mathrm{H},{ }_{\mathrm{N}} \underline{H}_{2} \mathrm{CH}_{2} \mathrm{CH}_{2} \mathrm{Me}\right)$, 4.3-4.5 (m, 8H, N $\underline{\mathrm{N}} \underline{H}_{2} \mathrm{CH}_{2} \mathrm{CH}_{2} \mathrm{Me} ; 2^{\text {nd }}$ isomer). ${ }^{13} \mathrm{C}\left\{{ }^{1} \mathrm{H}\right\} \mathrm{NMR}$ (125.75 MHz, THF-d8, $\left.25{ }^{\circ} \mathrm{C}\right): \quad \delta=12.9,12.8$ (s, $\mathrm{NCH}_{2} \mathrm{CH}_{2} \mathrm{CH}_{2} \underline{\mathrm{Me}}$ of two isomers), 19.9 (s, $\underline{P}-\underline{\mathrm{Me}}$ ), 23.7 (s, $\mathrm{NCH}_{2} \mathrm{CH}_{2} \underline{\mathrm{CH}}_{2} \mathrm{Me}$ ), 25.7 (s, $\mathrm{NCH}_{2} \underline{\mathrm{CH}}_{2} \mathrm{CH}_{2} \mathrm{Me}$ ), 32.8 (d, ${ }^{3} \mathrm{~J}_{\mathrm{P}, \mathrm{C}}=$ $\left.2.1 \mathrm{~Hz}, \quad \mathrm{NCH}_{2} \underline{\mathrm{CH}}_{2} \mathrm{CH}_{2} \mathrm{Me}\right), 32.9\left(\mathrm{~d},{ }^{3} J_{\mathrm{P}, \mathrm{C}}=2.2 \mathrm{~Hz}\right.$, $\mathrm{NCH}_{2} \underline{\mathrm{CH}}_{2} \mathrm{CH}_{2} \mathrm{Me} ; 2^{\text {nd }}$ isomer), 48.5 (ddd, ${ }^{3} J_{\mathrm{P}, \mathrm{C}}=9.6 \mathrm{~Hz}$, $\mathrm{N} \underline{\mathrm{H}}_{2} \mathrm{CH}_{2} \mathrm{CH}_{2} \mathrm{Me}$ ), 49.6 (ddd, ${ }^{3} J_{\mathrm{P}, \mathrm{C}}=8.3 \mathrm{~Hz},{ }_{\mathrm{NC}} \underline{H}_{2} \mathrm{CH}_{2} \mathrm{CH}_{2} \mathrm{Me}$; $2^{\text {nd }}$ isomer), $118.5\left(\mathrm{~d},{ }^{2} J_{\mathrm{P}, \mathrm{C}}=9.2 \mathrm{~Hz}, \mathrm{O}-\underline{C H}_{3}\right), 131.4$ (br, $\underline{P}-\underline{C}$ of the middle ring), $132.2\left(\mathrm{~d},{ }^{1 / 2} J_{\mathrm{P}, \mathrm{C}}=2.5 \mathrm{~Hz}, \underline{P}-\underline{C}\right.$ of the middle ring; $2^{\text {nd }}$ isomer), $223.4\left(\left(\mathrm{t},{ }^{3} J_{\mathrm{P}, \mathrm{C}}=2.7 \mathrm{~Hz}, \underline{C}^{2}\right), 224.2\left(\mathrm{t},{ }^{3} J_{\mathrm{P}, \mathrm{C}}=\right.\right.$ $2.7 \mathrm{~Hz}, \underline{C}^{2} ; 2^{\text {nd }}$ isomer). ${ }^{31} \mathrm{P}$ NMR (500 MHz, THF-d8, $\left.25{ }^{\circ} \mathrm{C}\right): \delta$ $=-74.0\left(\mathrm{~d},{ }^{3} J_{\mathrm{P}, \mathrm{H}}=4.8 \mathrm{~Hz}, \underline{P}-\underline{M e}\right),-68.6\left(\mathrm{~d},{ }^{3} J_{\mathrm{P}, \mathrm{H}}=3.7 \mathrm{~Hz}, \underline{P}-\right.$ $\underline{\mathrm{Me}}) ; 41.3\left(\mathrm{~d},{ }^{3} J_{\mathrm{P}, \mathrm{H}}=3.8 \mathrm{~Hz}\right) \& 37.2\left(\mathrm{~d},{ }^{3} J_{\mathrm{P}, \mathrm{H}}=4.6 \mathrm{~Hz}\right) . \operatorname{IR}\left[\mathrm{cm}^{-1}\right]$ : $\tilde{\nu}=2992.2(\mathrm{~m}), 2962.5(\mathrm{~m}), 2842.2(\mathrm{w}), 1501.2(\mathrm{w}), 1472.4(\mathrm{~m})$, 1415.8 (s), 1367.3 (s), 1146.0 (s), 1052.1 (m), 986.5 (m). Pos.
ESI-MS: $m / z(\%)=465.290(31)[\mathrm{M}+\mathrm{H}]^{\cdot+}\left[\mathrm{C}_{24} \mathrm{H}_{43} \mathrm{ON}_{4} \mathrm{P}_{2}\right]^{1+}$ theor./exp. 465.2907 (465.2909). UV/vis $\left(\mathrm{CH}_{2} \mathrm{Cl}_{2}\right): \lambda[\mathrm{nm}]$ (abs.): 347 (0.124).

7. To a solution of $3(2.0 \mathrm{~g}, 1.7 \mathrm{mmol})$ in dichloromethane, $[\mathrm{Rh}(\operatorname{cod}) \mathrm{Cl}]_{2} \quad(0.43 \mathrm{~g}, \quad 0.87 \mathrm{mmol})$ was added as solid at ambient temperature. Reaction mixture was stirred for 6 hours, at which point volatiles were removed in vacuo $(6 \times$ $10^{-3}$ mbar). Residue was washed (twice) with diethyl ether and subsequent drying in vacuo $\left(6 \times 10^{-3} \mathrm{mbar}\right)$ resulted in an orange solid. Yield: $2.1 \mathrm{~g}$ (1.5 mmol) $88 \%$; Orange solid; $\mathrm{M}$. p. $82{ }^{\circ} \mathrm{C} .{ }^{1} \mathrm{H}$ NMR $\left(300.1 \mathrm{MHz}, \mathrm{CD}_{2} \mathrm{Cl}_{2}, 25{ }^{\circ} \mathrm{C}\right): \delta=0.99(\mathrm{t}, 12 \mathrm{H}$, $\left.{ }^{3} J_{\mathrm{H}, \mathrm{H}}=7.2 \mathrm{~Hz}, \quad \mathrm{NCH}_{2} \mathrm{CH}_{2} \mathrm{CH}_{2} \underline{\mathrm{Me}}\right), 1.26-1.57(\mathrm{~m}, 8 \mathrm{H}$, $\left.\mathrm{NCH}_{2} \mathrm{CH}_{2} \underline{C H}_{2} \mathrm{Me}\right), 1.92(\mathrm{~m}, 4 \mathrm{H}, \operatorname{cod}), 1.99-2.21(\mathrm{~m}, 8 \mathrm{H}$, $\mathrm{NCH}_{2} \underline{\mathrm{CH}}_{2} \mathrm{CH}_{2} \mathrm{Me}$ ), 2.36 (m, $4 \mathrm{H}, \operatorname{cod}$ ), 2.56 (d, $8 \mathrm{H},{ }^{3} J_{\mathrm{P}, \mathrm{H}}=10.2$ $\left.\mathrm{Hz}, \mathrm{O}-\underline{C}_{3}\right), 3.68(\mathrm{~m}, 2 \mathrm{H}, \operatorname{cod}), 4.06-4.21(\mathrm{~m}, 8 \mathrm{H}$, $\mathrm{N}_{\underline{C}} \underline{H}_{2} \mathrm{CH}_{2} \mathrm{CH}_{2} \mathrm{Me}$ ), 5.37 (m, 2H, cod), 8.99 (brs, $\left.\mathrm{C}^{2}-\underline{H}\right) .{ }^{13} \mathrm{C}\left\{{ }^{1} \mathrm{H}\right\}$ NMR (125.75 MHz, $\left.\mathrm{CD}_{2} \mathrm{Cl}_{2}, 25{ }^{\circ} \mathrm{C}\right): \delta=13.46 \quad(\mathrm{~s}$, $\mathrm{NCH}_{2} \mathrm{CH}_{2} \mathrm{CH}_{2} \underline{\mathrm{Me}}$ ), 19.95 (s, $\mathrm{NCH}_{2} \mathrm{CH}_{2} \underline{\mathrm{CH}}_{2} \mathrm{Me}$ ), 28.52 (s, cod), 30.14 (br, $\mathrm{NCH}_{2} \underline{\mathrm{CH}}_{2} \mathrm{CH}_{2} \mathrm{Me}$ ), 33.27 (s, cod), 49.48 ((d, ${ }^{3} J_{\mathrm{P}, \mathrm{C}}=7.2$ $\mathrm{Hz}, \mathrm{NC}_{2} \underline{\mathrm{CH}}_{2} \mathrm{CH}_{2} \mathrm{Me}$ ), 69.6 (br, cod), 73.21 (d, ${ }^{1} J_{\mathrm{Rh}, \mathrm{C}}=11.2 \mathrm{~Hz}$, cod), 122.13 (q, $\left.{ }^{1} J_{\mathrm{P}, \mathrm{F}}=322.8 \mathrm{~Hz}, \underline{C F}_{3}\right), 108.68\left(\mathrm{~d},{ }^{2} J_{\mathrm{P}, \mathrm{C}}=11.1 \mathrm{~Hz}\right.$, $\mathrm{O}-\underline{\mathrm{CH}}_{3}$ ), 155.96 (br, $P-\underline{C}$ of the middle ring), 156.35 (d, ${ }^{1 / 2} J_{\mathrm{P}, \mathrm{C}}=$ $44.2 \mathrm{~Hz}, P-C$ of the middle ring), 137.96 (br, H-C $\left.{ }^{2}\right) .{ }^{31} \mathrm{P}$ NMR $\left(500.0 \mathrm{MHz}, \mathrm{CD}_{2} \mathrm{Cl}_{2}, 25{ }^{\circ} \mathrm{C}\right): \delta=-70.56(\mathrm{~s}), 47.45\left(\mathrm{~d},{ }^{1} J_{\mathrm{Rh}, \mathrm{P}}=\right.$ $188.2 \mathrm{~Hz})$. IR $\left[\mathrm{cm}^{-1}\right]: \tilde{\nu}=2975.2(\mathrm{~m}), 2931.4(\mathrm{~m}), 2840.1(\mathrm{w})$, $1511.4(\mathrm{~s}), 1480.4(\mathrm{~m}), 1398.1(\mathrm{~m}), 1247.8(\mathrm{~s}), 1175.5(\mathrm{~m})$, $1129.8(\mathrm{~m}), 1007.1(\mathrm{~s}), 910.2(\mathrm{~s})$. Neg. ESI-MS: $m / z(\%)=$ 995.151 (29) $[\mathrm{M}]^{\cdot+}$. HRMS: $\left[\mathrm{C}_{33} \mathrm{H}_{53} \mathrm{ClF}_{3} \mathrm{~N}_{4} \mathrm{O}_{7} \mathrm{P}_{2} \mathrm{RhS}_{2} \mathrm{~F}_{6}\right]^{+}$theor./ exp. 995.1473 (995.1494). UV/vis $\left(\mathrm{CH}_{2} \mathrm{Cl}_{2}\right): \lambda$ [nm] (abs.): 299 (0.924). EA [\%]: theor./exp. C 43.89/43.89, H 6.43/6.73, N 6.02/ 76.03, S 4.59/4.34.

$\mathbf{8}^{\text {cis/trans }}$. To a solution of $3(1.5 \mathrm{~g}, 1.3 \mathrm{mmol})$ in dichloromethane, 1.5 equivalent of $[\mathrm{Rh}(\operatorname{cod}) \mathrm{Cl}]_{2}(0.97 \mathrm{~g}, 1.9 \mathrm{mmol})$ was added as solid at ambient temperature. Reaction mixture was stirred at ambient temperature for 12 hours. Solvent was then removed in vacuo $\left(6 \times 10^{-3} \mathrm{mbar}\right)$ and the residue washed (twice) with diethyl ether. Subsequent drying in vacuo $\left(6 \times 10^{-3}\right.$ mbar) resulted in a dark orange solid. Yield: $1.7 \mathrm{~g}(0.9 \mathrm{mmol})$ $69 \%$; dark orange solid; (ratio of two isomers 1:0.7). M. p. $102{ }^{\circ} \mathrm{C} .{ }^{1} \mathrm{H}$ NMR $\left(500.1 \mathrm{MHz}, \mathrm{CD}_{2} \mathrm{Cl}_{2}, 25{ }^{\circ} \mathrm{C}\right): \delta=1.1-1.2(\mathrm{t}$, $\left.12 \mathrm{H},{ }^{3} J_{\mathrm{H}, \mathrm{H}}=7.0 \mathrm{~Hz}, \mathrm{NCH}_{2} \mathrm{CH}_{2} \mathrm{CH}_{2} \underline{\mathrm{Me}}\right), 1.5-1.7(\mathrm{~m}, 8 \mathrm{H}$, $\left.\mathrm{NCH}_{2} \mathrm{CH}_{2} \underline{\mathrm{CH}}_{2} \mathrm{Me}\right), 2.2-2.4(\mathrm{~m}, 24 \mathrm{H}, \operatorname{cod}), 2.5-2.6(\mathrm{~m}, 8 \mathrm{H}$, $\left.\mathrm{NCH}_{2} \underline{\mathrm{CH}}_{2} \mathrm{CH}_{2} \mathrm{Me}\right), 2.9,3.0\left(\mathrm{~d}, 3 \mathrm{H},{ }^{3} \mathrm{~J}_{\mathrm{P}, \mathrm{H}}=12.4 \mathrm{~Hz}, \mathrm{O}-\underline{C}_{3} \underline{H}_{3}\right), 3.9$ (m, 6H, cod), 4.2 (br, 8H, $\underline{N C H}_{2} \mathrm{CH}_{2} \mathrm{CH}_{2} \mathrm{Me}$ ), 5.2 (m, 6H, cod), 9.5 (brs, $\mathrm{C}^{2}-\underline{H}$ ), 9.7 (brs, $\mathrm{C}^{2}-\underline{H}$ ). ${ }^{13} \mathrm{C}\left\{{ }^{1} \mathrm{H}\right\}$ NMR $(125.75 \mathrm{MHz}$, $\left.\mathrm{CD}_{2} \mathrm{Cl}_{2}, 25{ }^{\circ} \mathrm{C}\right): \delta=13.5,13.8\left(\mathrm{~s}, \mathrm{NCH}_{2} \mathrm{CH}_{2} \mathrm{CH}_{2} \underline{\mathrm{Me}}\right.$ ) two isomers, 19.9, 20.1 (s, $\mathrm{NCH}_{2} \mathrm{CH}_{2} \underline{\mathrm{C}}_{2} \mathrm{Me}$ ) two isomers, 28.4 (s, cod), 31.3 (br, $\mathrm{NCH}_{2} \underline{\mathrm{CH}}_{2} \mathrm{CH}_{2} \mathrm{Me}$ ), 32.7 (s, cod), 49.9 (d, ${ }^{3} \mathrm{~J}_{\mathrm{P}, \mathrm{C}}=$ $6.3 \mathrm{~Hz}, \underline{N}_{\underline{H}} \underline{C H}_{2} \mathrm{CH}_{2} \mathrm{Me}$ ), 49.9 (br, $\underline{\mathrm{N}}_{\underline{H}} \mathrm{CH}_{2} \mathrm{CH}_{2} \mathrm{Me}$ ), 72.0 (d, $\left.{ }^{1} J_{\mathrm{Rh}, \mathrm{C}}=13.0 \mathrm{~Hz}, \operatorname{cod}\right), 72.6\left(\mathrm{~d},{ }^{1} J_{\mathrm{Rh}, \mathrm{C}}=13.0 \mathrm{~Hz}, \operatorname{cod}\right), 73.21(\mathrm{~d}$, $\left.{ }^{1} J_{\mathrm{Rh}, \mathrm{C}}=13.1 \mathrm{~Hz}, \operatorname{cod}\right), 74.2\left(\mathrm{~d},{ }^{1} J_{\mathrm{Rh}, \mathrm{C}}=13.2 \mathrm{~Hz}, \operatorname{cod}\right), 74.6(\mathrm{~d}$, $\left.{ }^{1} J_{\mathrm{Rh}, \mathrm{C}}=13.0 \mathrm{~Hz}, \operatorname{cod}\right), 75.4\left(\mathrm{~d},{ }^{1} J_{\mathrm{Rh}, \mathrm{C}}=13.1 \mathrm{~Hz}, \operatorname{cod}\right), 113.4(\mathrm{~d}$, $\left.{ }^{2} J_{\mathrm{P}, \mathrm{C}}=9.5 \mathrm{~Hz}, O-\underline{C}_{3}\right), 121.1\left(\mathrm{q},{ }^{1} J_{\mathrm{P}, \mathrm{F}}=332.7 \mathrm{~Hz}, \underline{C F}_{3}\right), 131.9$ (br, $\underline{P}-\underline{C}$ of the middle ring), $133.3\left(\mathrm{~d},{ }^{1 / 2} J_{\mathrm{P}, \mathrm{C}}=45.2 \mathrm{~Hz}, \underline{P}-\underline{C}\right.$ of the middle ring), 141.9 (br, $\left.\mathrm{H}-\underline{C}^{2}\right), 142.4$ (br, $\left.\mathrm{H}-\underline{C}^{2}\right) 2^{\text {nd }}$ isomer. ${ }^{31} \mathrm{P}$ NMR $\left(500.0 \mathrm{MHz}, \mathrm{CD}_{2} \mathrm{Cl}_{2}, 25^{\circ} \mathrm{C}\right): \delta=65.0\left(\mathrm{~d},{ }^{1} J_{\mathrm{Rh}, \mathrm{P}}=195.6\right.$ 
$\mathrm{Hz}$ ) (minor)/64.1 (dd, ${ }^{1} J_{\mathrm{Rh}, \mathrm{P}}=200.1 \mathrm{~Hz},{ }^{3} J_{\mathrm{P}, \mathrm{P}}=5.3 \mathrm{~Hz}$ ) (major) and $-120.3\left(\mathrm{t} \mathrm{br},{ }^{1} J_{\mathrm{Rh}, \mathrm{P}}=126.9 \mathrm{~Hz}\right)($ major$) /-123.4\left(\mathrm{t},{ }^{1} J_{\mathrm{Rh}, \mathrm{P}}=\right.$ $126.9 \mathrm{~Hz}$ ) (minor). IR $\left[\mathrm{cm}^{-1}\right]: \tilde{\nu}=2984.1(\mathrm{~m}), 2971.0(\mathrm{~m})$, $2861.8(\mathrm{w}), 1545.0(\mathrm{~s}), 1491.7(\mathrm{~m}), 1421.1(\mathrm{~m}), 1327.8(\mathrm{~s})$, 1265.6 (m), 1129.8 (w), 1069.1 (s), 978.0 (s). Pos. ESI-MS: m/z $(\%)=1153.205$ (36) $[\mathrm{M}-\mathrm{Cl}-2 \mathrm{TfO}]^{\circ+}$. HRMS: $\left[\mathrm{C}_{47} \mathrm{H}_{76} \mathrm{Cl}_{2} \mathrm{~N}_{4} \mathrm{OP}_{2} \mathrm{Rh}_{3}\right]^{{ }^{+}}$theor./exp. 1153.2031 (1153.2043). UV/ vis $\left(\mathrm{CH}_{2} \mathrm{Cl}_{2}\right): \lambda[\mathrm{nm}]$ (abs.): 386 (0.216). EA [\%]: theor./exp. C 42.61/41.38, H 6.03/6.04, N 4.45/4.22, S 3.40/3.62.

\section{Conclusion}

The first example of an anionic P-bridged tricyclic bis(NHC) was obtained via an unexpected reductive deselenization combined with a subsequent deprotonation of the bis(imidazolium) salt. Reaction of the latter with $\mathrm{MeI}$ as electrophile resulted finally in the first example of a neutral P-functional bis(NHCs) with a mixed substitution pattern. Initial studies of the coordination properties of the tricyclic bis(imidazolium) salt revealed a pre-ference of the neutral P-ligands site over the anionic phosphorus centre. Detailed electrochemical studies of the anionic bis(NHC) showed multiple, closely spaced oxidation processes owing, most probably, to the formation of a short lived P-centred radical that yields a new intermediate, a tetrakis(NHC), having a P-P bond linkage.

\section{Conflicts of interest}

There are no conflicts of interest to declare.

\section{Acknowledgements}

We are grateful to the University of Bonn for financial support. The reinvitation grants for R. T. B. and L. N. from the Alexander von Humboldt Foundation are acknowledged. Z. K. is grateful for the general support of Hungarian Academy of Science under the Premium Postdoctoral Research Program 2019.

\section{Notes and references}

1 (a) For some books, see: N-Heterocyclic Carbenes in Synthesis, ed. S. P. Nolan, Wiley-VCH, Weinheim, 2006 (b) S. D. Gonzalez, N-Heterocyclic, Carbenes: From Laboratory Curiosities To Efficient Synthetic Tools, Royal Society of Chemistry, Cambridge, U.K., 2011.

2 (a) F. E. Hahn and M. C. Jancke, Angew. Chem., Int. Ed., 2008, 47, 3122; (b) K. J. Cavell, Dalton Trans., 2008, 6676; (c) V. César, S. Bellemin-Laponnaz and L. H. Gade, Chem. Soc. Rev., 2004, 33, 619; (d) D. Bourissou, O. Guerret, F. Gabbal and G. Bertrand, Chem. Rev., 2000, 100, 32; (e) M. N. Hopkinson, C. Richter, M. Schedler and F. Glorius, Nature, 2014, 510, 485; $(f)$ A. Prades, E. Peris and M. Alcarazo, Organometallics, 2012, 31, 4623; (g) H. Valdes, M. Poyatos and E. Peris, Organometallics, 2015, 34, 1725.

3 (a) S. Conde-Guadano, M. Hanton, R. P. Tooze, A. A. Danopoulos and P. Braunstein, Dalton Trans., 2012, 41, 12558; (b) S. Conde-Guadano, A. A. Danopoulos, R. Pattacini, M. Hanton and R. P. Tooze, Organometallics, 2012, 31, 1643; (c) N. Vujkovic, V. Cesar, N. Lugan and G. Lavigne, Chem. - Eur. J., 2011, 17, 13151; (d) A. Carter, A. Mason, M. A. Baker, D. G. Bettler, A. Changas, C. D. McMillen and D. Tapu, Organometallics, 2017, 36, 1867.

4 D. Mendoza-Espinosa, B. Donnadieu and G. Bertrand, Chem. - Asian J., 2011, 6, 1099.

5 L. Benhamou, V. César, H. Gornitzka, N. Lugan and G. Lavigne, Chem. Commun., 2009, 4720.

6 S. Kronig, E. Theuergarten, C. G. Daniliuc, P. G. Jones and M. Tamm, Angew. Chem., Int. Ed., 2012, 51, 3240.

7 A. A. Danopoulos, K. Y. Monakhov and P. Braunstein, Chem. - Eur. J., 2013, 19, 450.

8 P. K. Majhi, G. Schnakenburg, Z. Kelemen, L. Nyulaszi, D. P. Gates and R. Streubel, Angew. Chem., Int. Ed., 2013, 52, 10080.

9 (a) N. Vujkovic, V. César, N. Lugan and G. Lavigne, Chem. Eur. J., 2011, 17, 13151; (b) D. Mendoza-Espinosa, B. Donnadieu and G. Bertrand, Chem. - Asian J., 2011, 6, 1099.

10 D. M. Khramov, A. J. Boydston and C. W. Bielawski, Angew. Chem., Int. Ed., 2006, 45, 6186.

11 P. K. Majhi, A. Koner, G. Schnakenburg, Z. Kelemen, L. Nyulászi and R. Streubel, Eur. J. Inorg. Chem., 2016, 3559.

12 (a) N. R. Naz, G. Schnakenburg, A. Mikeházi, Z. Kelemen, L. Nyulászi, R. T. Boeré and R. Streubel, Chem. Commun., 2020, 56, 2646; (b) for a recent account on bis(NHCs), see: S. Ibáñez, M. Poyatos and E. Peris, Acc. Chem. Res., 2020, 53, 1401.

13 A. Koner, G. Pfeifer, Z. Kelemen, G. Schnakenburg, L. Nyulászi, T. Sasamori and R. Streubel, Angew. Chem., Int. Ed., 2017, 56, 9231.

$141^{\prime}, 2^{\prime}, 3^{\prime}, 4^{\prime}, 5^{\prime \text { cis/trans }}, 6^{\prime \text { cis/trans }}$ calculated compounds with methyl substituents at $\mathrm{N}$ and for ions without counter ions; see also ref. $12 a$ and 13 .

15 Z. Kelemen, R. Streubel and L. Nyulászi, RSC Adv., 2015, 5, 41795.

16 I. Begum, G. Schnakenburg, Z. Kelemen, L. Nyulászi, R. T. Boeré and R. Streubel, Chem. Commun., 2018, 54, 13555.

17 (a) SHELXS-97: G. M. Sheldrick, Acta Crystallogr., Sect. A: Found. Crystallogr., 1990, 46, 467; (b) G. M. Sheldrick, SHELXL-97, University of Göttingen, Göttingen, Germany, 1997. 